\title{
Differential in vitro pathogenicity of predatory fungi of the genus Monacrosporium for phytonematodes, free-living nematodes and parasitic nematodes of cattle
}

A.P.S. Gomes ${ }^{1}$

J.V. Araújo $0^{1}$ and

R.C.F. Ribeiro ${ }^{2}$
${ }^{1}$ D epartamentos de Veterinária e ${ }^{2}$ Fitopatologia, Universidade Federal de Viçosa, Viçosa, MG, Brasil

\section{Correspondence}

J.V. Araújo

Departamento de Veterinária, UFV

36571-000 Viçosa, MG

Brasil

Fax: + 55-31-899-2317

E-mail: jvictor@mail.ufv.br

Received O ctober 28, 1997 Accepted October 6, 1998

\section{Abstract}

In vitro tests were carried out on the pathogenicity of nine isolates of the predatory fungi of the genus Monacrosporium (5 M. sinense isolates, $3 \mathrm{M}$. appendiculatum and $1 \mathrm{M}$. thaumasium isolate) for a phytonematode (second stage juveniles from Meloidogyne incognita, race 3), a free-living nematode (Panagrellus spp), and two gastrointestinal parasitic nematodes of cattle (infective larvae of Cooperia punctata and Haemonchus placei). A suspension containing 2,000 nematodes from each species was added to Petri dishes containing fungi and grown on $2 \%$ water-agar medium at $25^{\circ} \mathrm{C}$ in the dark for up to 7 days. The dishes were examined every other day for 7 days and predation-free nematodes were counted. The results showed that the free-living nematodes, Panagrellus spp, were the most susceptible $(\mathrm{P}<0.05)$, followed by the phytonematode $M$. incognita, while the controls were $\geq 98.5 \%$ viable. However, a variable susceptibility of the nematodes to different fungi was observed. This indicates that the use of predatory fungi for the environmental control of nematodes will be limited by the multiplicity of nematodes in the environment and their differential susceptibility to fungal isolates of the same genus.
Key words

- Nematophagous fungi

- Nematode-trapping fungus

- Predacious fungi

- Monacrosporium

- Nematode

- Cooperia punctata

- Haemonchus placei

- Meloidogyne incognita

- Panagrellus

\section{Introduction}

Biological control based on the use of microorganisms is a promising alternative for the control of nematodes. Organisms such as fungi, bacteria, viruses and protozoa have been identified as nematode parasites or predators (1). Nematode-destroying fungi produce traps at intervals along their hyphae. Many of these fungi will not form traps in pure culture, and the formation of these structures is the fungal response to the presence of nematodes, substances derived from them, or other compounds of biological origin, induced by adverse culture conditions such as water and/or nutrient scarcity (2). Hyphal differentiation can occur within $24 \mathrm{~h}$ and various trapping structures can be produced (3). Six main types of traps are known: non-modified or non-differentiated adhesive hyphae, anastomosed hyphal branches forming tridimensional adhesive nets, adhesive 
branches, sometimes forming simple nets and, most of the times, bidimensional nets, adhesive nodules, and constricting and nonconstricting rings (4). Predatory fungi of the Monacrosporium genus were classified by Cooke and Dickson (5) as belonging to the subdivision Deuteromycotina. These fungi produce adhesive nodules which are round cells coated with adhesive material and located at the apex of a non-adhesive hypha, and/or tridimensional nets, also covered with adhesive material (6). The free-living nematode Panagrellus spp has been used in various studies as a model nematode for tests of nematode-destroying fungi. The objective of the present study was to compare the pathogenicity of isolates of the fungus Monacrosporium for various nematode groups.

\section{Material and Methods}

Infective larvae (L3) of Cooperia punctata and Haemonchus placei were provided by Professor Maria Cecília Reale Vieira-Bressan, Department of Parasitology, University of São Paulo (USP). Panagrellus (free-living nematodes) and second stage larvae (L2) of Meloidogyne incognita, race 3, were provided by Professor Silamar Ferraz, Department of Phytopathology, Federal University of Viçosa (UFV). In order to eliminate bacteria and fungi, the nematodes were washed 10 times in distilled water by centrifugation at 1,000 rpm for $5 \mathrm{~min}$ and the supernatants were discarded at the end of each centrifugation. The nematodes were stored at $4{ }^{\circ} \mathrm{C}$ for one week in a solution containing $0.05 \%$ streptomycin sulfate, $0.05 \%$ chloramphenicol and $0.05 \%$ amphotericin $\mathrm{B}$, and the washing process was repeated as described. The nematodes were counted in three $10-\mu 1$ aliquots under the light microscope (10X) and the counts were averaged.

Nine isolates of predatory fungi of the genus Monacrosporium were maintained in test tubes containing $2 \%$ potato-dextrose- agar $\left(2 \%\right.$ PDA) at $4{ }^{\circ} \mathrm{C}$ in the dark. These isolates comprised $5 \mathrm{M}$. sinense isolates (A, $\mathrm{B}, \mathrm{C}, \mathrm{D}$ and $\mathrm{E}), 3 \mathrm{M}$. appendiculatum isolates $(\mathrm{F}, \mathrm{G}$ and $\mathrm{H})$, and $1 \mathrm{M}$. thaumasium isolate (I), and were originally obtained from soils at various locations in Brazil. Culture discs were removed from Petri dishes measuring $8.5 \mathrm{~cm}$ in diameter and containing 20 $\mathrm{ml}$ of $2 \%$ PDA culture medium. The fungi grew on these dishes for 7 days at $25^{\circ} \mathrm{C}$ in the dark. Mycelium discs measuring $7 \mathrm{~mm}$ in diameter were removed from the edges of the PDA cultures and transferred to Petri dishes containing $2 \%$ water-agar medium ( $2 \% \mathrm{WA}$ ) and $0.5 \mathrm{mg} / 100 \mathrm{ml}$ gentamicin. These dishes were kept in an incubator at $25^{\circ} \mathrm{C}$ for 5 days in the dark. On the 6 th day, $1 \mathrm{ml}$ of the suspension containing 2,000 nematodes from each group or species was added to these dishes. Starting $24 \mathrm{~h}$ later, the dishes were examined under the microscope (4X) every other day for 7 days, and predation-free nematodes were counted. The dishes were kept in the dark at $25^{\circ} \mathrm{C}$. Experiments were performed in triplicate. The control group for each genus of nematode employed consisted of three plates, each containing only $2 \%$ WA plus 2,000 nematodes. The results were analyzed by the least significant difference test $(\mathrm{P}<0.05)$ (7).

\section{Results}

Figure 1 shows the results of the trap tests with isolates A, B, C, D, E, F, G, H and I and the various nematodes. Isolate $F$ (M. appendiculatum) was the most effective fungus against all the nematode groups.

The free-living nematode (Panagrellus spp) was more susceptible than the other nematodes to predation by all the fungal isolates $(\mathrm{P}<0.05)$ and less than $40(2 \%)$ were viable from day one on. No significant differences in susceptibility to predation were observed among the other nematodes (Figure 1).

The phytonematode Meloidogyne incog- 

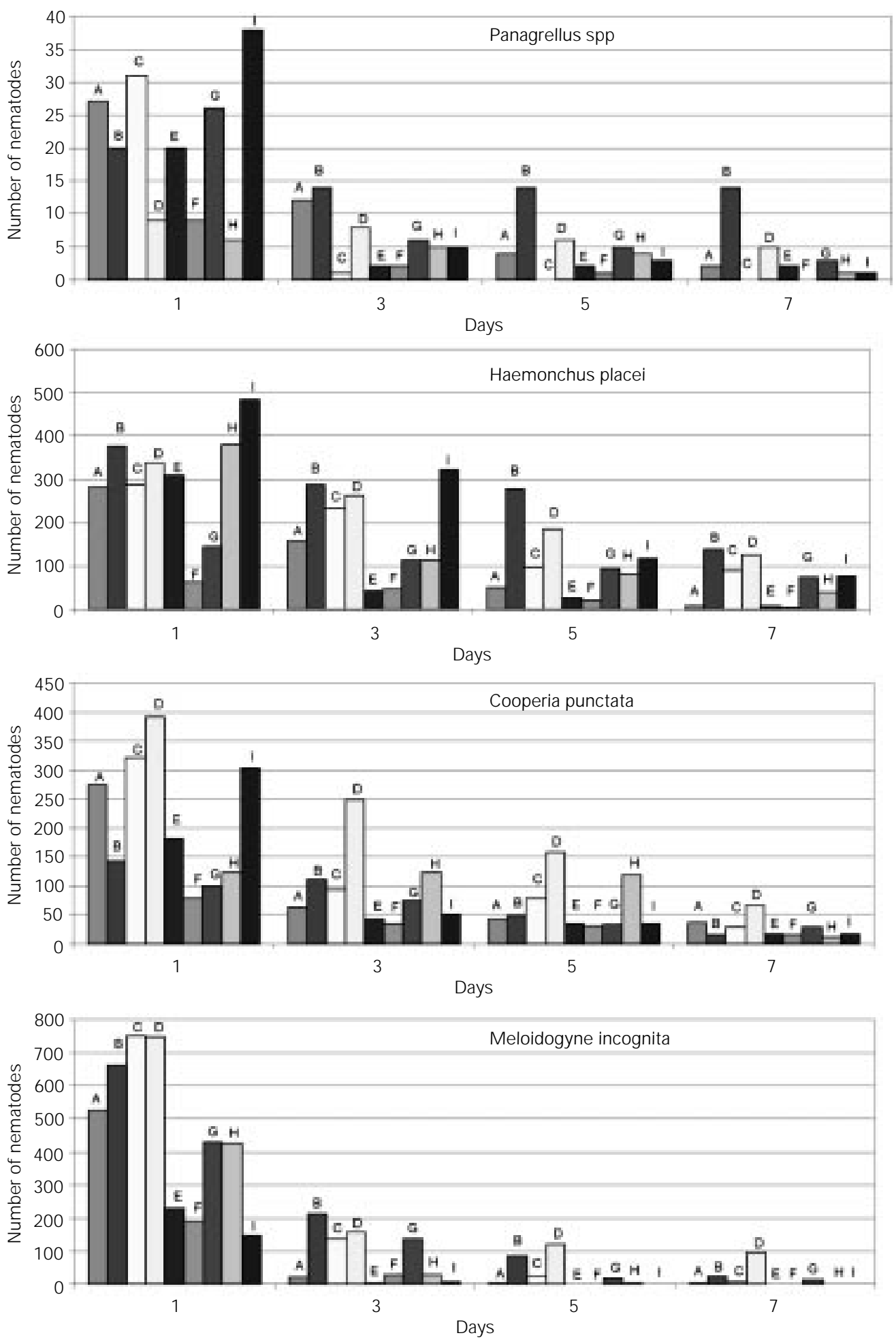

Figure 1 - Susceptibility of nematodes to infection by fungi. Data are reported as number of nematodes free from fungal infection on days 1 to 7 after 2,000 nematodes were exposed to Monacrosporium sinense (isolates A, B, C, $\mathrm{D}$ and $\mathrm{E}$ ), $\mathrm{M}$. appendiculatum (isolates $\mathrm{F}, \mathrm{G}$ and $\mathrm{H}$ ) and $\mathrm{M}$. thaumasium (isolate I). Data are the means of measurements in triplicate and control values were $\geq 1970$ (98.5\%). Note that the abscissae of the four panels are different. 
nita was much more susceptible to all fungal isolates than $C$. punctata and $H$. placei $(\mathrm{P}<0.05)$ except for fungal isolate $\mathrm{B}$, to which $C$. punctata larvae were more susceptible. M. incognita was also less susceptible to fungal isolate $\mathrm{G}$ when considering days 1 and 3. The nematode C. punctata was more susceptible than $H$. placei $(\mathrm{P}<0.05)$ to treatment with fungal isolates $\mathrm{B}, \mathrm{C}, \mathrm{G}, \mathrm{I}$ and $\mathrm{H}$. There were no statistically significant differences between the remaining treatments. The control viabilities were $\geq 98.5 \%$.

Fungal isolates $\mathrm{C}$ and D were weakly effective against $H$. placei, C. punctata and $M$. incognita, especially during the first days.

\section{Discussion}

The present results show that free-living nematode Panagrellus spp, followed by $M$. incognita, were more susceptible than the other nematodes to most of the fungal isolates of Monacrosporium studied. The nematodes C. punctata and H. placei were the least susceptible.

We have previously shown that Monacrosporium ellipsosporum can control infective $H$. placei in vitro (8). We have also shown that among several nematophagous fungi such as Paecilomyces lilacinus, Cylindrocarpon sp, Trichoderma harzianum, Dactylaria thaumasia, Arthrobotrys robusta and M. ellipsosporum, only M. ellipsosporum showed the potential to control the nematode $M$. incognita under greenhouse conditions (9). Another study (10) of the fungi Verticillium chlamydosporium and six species of Monacrosporium for the control of M. incognita, M. ameliae and M. ellipsosporum were the most efficient during the last reading days. In the present experiment, the fungal isolate $\mathrm{F}$ was the most effective against $H$. placei and C. punctata as compared to other treatments $(\mathrm{P}<0.05)$. Fungi $\mathrm{E}$,
$\mathrm{F}$ and I were more effective against $M$. incognita larvae than other fungi isolates $(\mathrm{P}<0.05)$. Throughout the study there was a statistically significant difference in the number of nematodes between the treatment groups and the controls. The numbers of living nematodes in each control group were always above 1970 on all reading days.

Taken together, these data underscore the variable susceptibility of different nematodes to different fungal isolates of the same genus. This suggests that in vitro studies are important prior to the application of these fungi to the biological control of nematodes since free-living nematodes, phytonematodes and cattle parasitic nematodes are generally associated in the environment. However, the value of in vitro tests for the study of nematophagous fungi is limited since these tests usually overestimate the activity of a fungus in a small environment where the nematode is not allowed to escape, and do not reproduce the possible interference of the soil.

Fungi of the genus Monacrosporium may become useful in the biological control of nematodes in the future. However, as demonstrated in the present study, the presence of multiple nematode species in the environment and the variable predatory ability shown by different species and isolates of Monacrosporium indicate that the usefulness of this approach will be limited by the choice of a given fungal isolate for a particular environment.

\section{Acknowledgments}

The authors wish to thank Drs. VieiraBressan, from the University of São Paulo, and Ferraz, from the Federal University of Viçosa, for providing nematodes for the study. 


\section{References}

1. Van Gundy SD (1985). Biological control of nematodes. In: Hoy MA \& Herzog DC (Editors), Biological Control in Agricultural IPM Systems. Vol. I. Academic Press, New York

2. Balan J \& Gerber N (1972). Attraction and killing of the nematode Panagrellus redivivus by the predacious fungus Arthrobotrys dactiloides. Nematologica, 18: 163-173.

3. Pramer D (1964). Nematode-trapping fungi. Science, 144: 382-388.

4. Gray NF (1988). Fungi attacking vermiform nematodes. In: Poinar J r GO \& $J$ ansson HB (Editors), Diseases of Nematodes. Vol. II. CRC Press, Boca Raton.
5. Cooke RC \& Dickson AL (1965). Nematode-trapping species of Dactylella and Monacrosporium. Transactions of the British Mycological Society, 48: 621-629.

6. Barron GL (1977). The Nematode-Destroying Fungi. 1st edn. Canadian Biological Publications, Guelph.

7. Snedecor GW \& Cochran WG (1976). Statistical Methods. 6th edn. Iowa University College, Ames.

8. Araújo J V, Santos MA, Ferraz S, Maia AS \& Magalhães ACM (1992). Controle de lanvas infectantes de Haemonchus placei por fungos predadores da espécie Monacrosporium ellypsosporum em condições de laboratório. Arquivo Brasileiro de Me- dicina Veterinária e Zootecnia, 44: 521526.

9. Santos MA (1991). Detecção, identificação e avaliação do potencial antagonista de fungos nematófagos presentes em solos do Brasil. Master's thesis, Universidade Federal de Viçosa, Viçosa, MG, Brasil.

10. Pria MD (1992). Controle biológico de Meloidogyne incognita, raça 3 , pelos fungos Verticillium chlamydosporium e espécies de Monacrosporium, isolados ou combinados. Master's thesis, Universidade Federal de Viçosa, Viçosa, MG, Brasil. 